\title{
OVERLAP IN THE TYPE AND SIZE OF THE PREY THAT COMPOSE THE DIET OF THE PACIFIC SARDINE Sardinops caeruleus (GIRARD, 1856), THREAD HERRING Opisthonema libertate (GUNTHER, 1867) AND NORTHERN ANCHOVY Engraulis mordax (GIRARD, 1856) IN THE GULF OF CALIFORNIA
}

\section{TRASLAPO EN EL TIPO Y TAMAÑO DE LAS PRESAS QUE FORMAN LA DIETA DE LA SARDINA MONTERREY Sardinops caeruleus (GIRARD, 1856), LA SARDINA CRINUDA Opisthonema libertate (GUNTHER, 1867) Y LA ANCHOVETA NORTEÑA Engraulis mordax (GIRARD, 1856) EN EL GOLFO DE CALIFORNIA}

\author{
Juana López-Martínez ${ }^{1,2}$ \\ Manuel O. Nevárez-Martínez ${ }^{3}$ \\ Raúl E. Molina-Ocampo ${ }^{1,3}$ \\ Fernando A. Manrique-Colchado ${ }^{1,4}$ \\ ${ }^{1}$ Instituto Tecnológico y de Estudios Superiores de Monterrey, Campus Guaymas \\ Apartado postal 484, Guaymas, CP 85400, Sonora, México \\ ${ }^{2}$ Centro de Investigaciones Biológicas del Noroeste, Unidad Guaymas \\ Apartado postal 349, Guaymas, CP 85400, Sonora, México \\ E-mail: jlopez@cibnor.mx \\ ${ }^{3}$ Centro Regional de Investigación Pesquera, Instituto Nacional de la Pesca \\ Calle 20 \#605 Sur, Guaymas, CP 85400, Sonora, México \\ E-mail: cripgym@son1.telmex.net.mx \\ ${ }^{4}$ Centro de Calidad Ambiental, Instituto Tecnológico y de Estudios Superiores de Monterrey \\ Sucursal de correos "J", Monterrey, CP 64849, Nuevo León, México \\ E-mail: fmanriqu@ campus.mty.itesm.mx
}

Recibido en noviembre de 1998; aceptado en junio de 1999

\begin{abstract}
We present the results of the analysis of overlap in the diet of the Pacific sardine Sardinops caeruleus, the northern anchovy Engraulis mordax and the thread herring Opisthonema libertate. These are the most commercially important species of small pelagic fishes in the fishery that is developed in the Gulf of California. Although the diet of these species is very similar, the overlap is only significant between the northern anchovy and the thread herring. As these two species do not overlap spatially in the Gulf of California, the possibility of competition for food between them is considered unlikely.
\end{abstract}

Key words: small pelagic fishes, overlap, diet, Gulf of California. 
Ciencias Marinas, Vol. 25, No. 4, 1999

\section{RESUMEN}

Se presentan los resultados del análisis de traslapo en la dieta de la sardina monterrey Sardinops caeruleus, la anchoveta norteña Engraulis mordax y la sardina crinuda Opisthonema libertate. Éstas son las especies de pelágicos menores de mayor importancia económica en la pesquería que se desarrolla en el Golfo de California. Si bien la dieta de estas especies es muy similar, el traslapo sólo fue significativo entre la anchoveta norteña y la sardina crinuda. Sin embargo, debido a que estas dos especies no se traslapan espacialmente en el Golfo de California, la posibilidad de competencia por alimento entre ellas se considera poco probable.

Palabras clave: peces pelágicos menores, traslapo, dieta, Golfo de California.

\section{INTRODUCTION}

Small pelagics are groups of marine fishes that form large schools, of cosmopolitan distribution, and that sustain large-scale fisheries worldwide, providing over $80 \%$ of the world fish production in 1993 (Blaxter and Hunter, 1982; Lluch-Belda et al., 1989, 1992, 1994; Kawasaki, 1993; Csirke, 1995). Currently, they are extensively fished in five major upwelling ecosystems: Kuroshio, California, Humboldt, Benguela and the Canarias Current (Lluch-Belda et al., 1992; Kawasaki, 1993). Several genera of small pelagics co-occur in each one of these ecosystems, the most important being Sardinops (sardines), Engraulis (anchovies), Scomber (mackerels) and Opisthonema (thread herrings). Populations of these organisms undergo large fluctuations, with alternating periods of high abundance of sardines and low abundance of anchovies, and vice versa (Lluch-Belda et al., 1989, 1992; Kawasaki, 1993). Hypothetically, these changes in abundance are in response to large-scale climatic changes (Lluch-Belda et al., 1989, 1992).

In the Gulf of California, a fishery of small pelagic fishes exists that reached about 320,000 metric tons (t) during the 1988/1989 season, then decreased to $55,000 \mathrm{t}$ in $1992 / 1993$, and again increased to $230,000 \mathrm{t}$ during the 1996/1997 season (fig. 1) (Nevárez-Martínez et al., 1998). This fishery includes several species (CisnerosMata et al., 1991; Nevárez-Martínez et al., 1993): the Pacific sardine (Sardinops caeruleus), thread

\section{INTRODUCCIÓN}

Los pelágicos menores son grupos de peces marinos que forman grandes cardúmenes, de distribución cosmopolita y que soportan pesquerías a gran escala a través del mundo. Este grupo aportó cerca del $80 \%$ a la producción mundial de peces en 1993 (Blaxter y Hunter, 1982; Lluch-Belda et al., 1989, 1992, 1994; Kawasaki, 1993; Csirke, 1995). Actualmente, se pescan extensivamente en cinco grandes sistemas de surgencias: Kuroshio, California, Humboldt, Benguela y la Corriente de Las Canarias (Lluch-Belda et al., 1992; Kawasaki 1993). En cada uno de estos ecosistemas, coocurren varios géneros de peces pelágicos menores, siendo los géneros más importantes Sardinops (sardinas), Engraulis (anchovetas), Scomber (macarelas) y Opisthonema (crinudas o arenques de hebra). Las poblaciones de estos organismos experimentan grandes fluctuaciones, alternando periodos de alta abundancia de sardinas y baja abundancia de anchovetas y viceversa (Lluch-Belda et al., 1989, 1992; Kawasaki, 1993). Se ha hipotetizado que estos cambios en la abundancia están relacionados con cambios climáticos de gran escala (Lluch-Belda et al., 1989, 1992).

En el Golfo de California existe una pesquería de pelágicos menores que alcanzó capturas de más de 320,000 toneladas métricas (t) durante la temporada 1988/1989, luego disminuyó a 55,000 t en 1992/1993, para posteriormente aumentar nuevamente a 230,000 t durante la temporada 1996/1997 (fig. 1) (Nevárez-Martínez et al., 


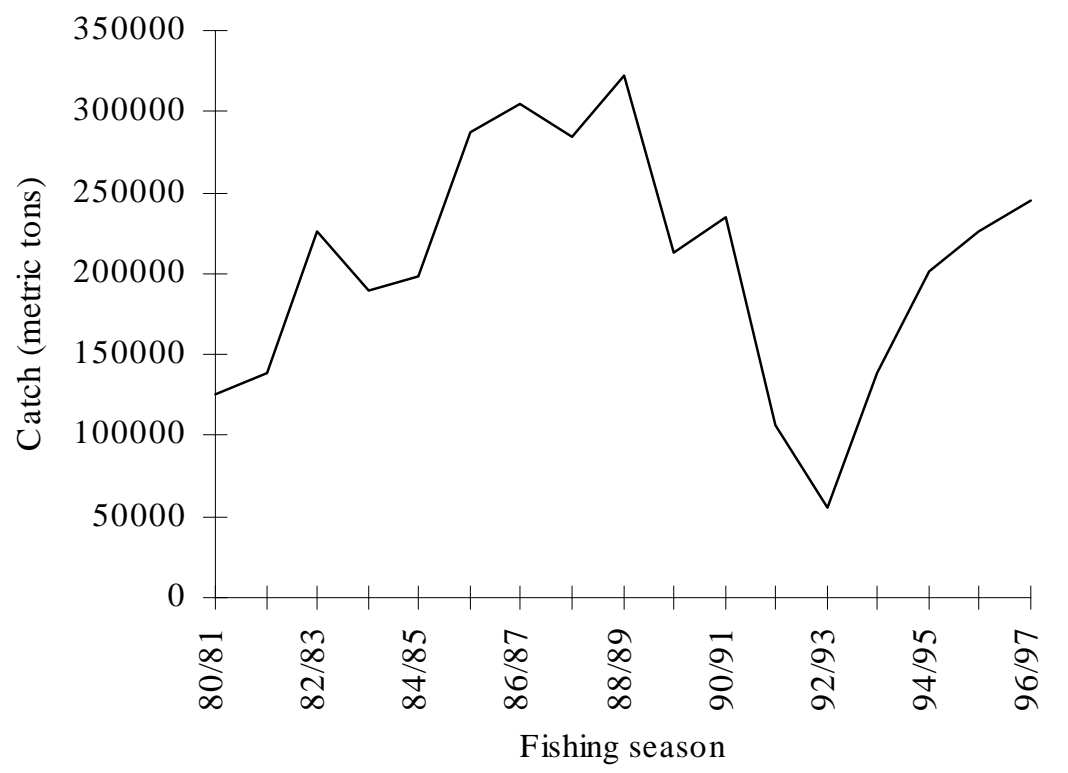

Figure 1. Total catch of small pelagics in the Gulf of California, Mexico.

Figura 1. Captura total de pelágicos menores en el Golfo de California, México.

herring (Opisthonema libertate), northern anchovy (Engraulis mordax), Pacific mackerel (Scomber japonicus), round herring (Etrumeus teres) and anchovy (Cetengraulis mysticetus). The first four species represented $99 \%$ of the catch during the 1995/1996 season, with the Pacific sardine providing 88\% (Nevárez-Martínez et al., 1996).

Most of the small pelagics are filter and particulate feeders (Radovich, 1952; Hand and Berner, 1959; Ahlstrom, 1960; Ciechomski, 1967; Murphy, 1977; Kawasaki and Kumagai, 1984; Cury and Fontana, 1988; López-Martínez, 1991; Jacob-Cervantes et al., 1992; Molina-Ocampo, 1993). The genus Sardinops is a member of several quite complex communities of plankton feeders and it can establish competition with other species of high economic importance. An example of this is the interactive complex formed by Sardinops, Engraulis, Scomber and Trachurus in California (Murphy, 1977). Similar communities are established in southeast Africa, and in coastal
1998). Esta pesquería incluye varias especies (Cisneros-Mata et al., 1991; Nevárez-Martínez et al., 1993): sardina monterrey (Sardinops caeruleus), sardina crinuda (Opisthonema libertate), anchoveta norteña (Engraulis mordax), macarela (Scomber japonicus), sardina japonesa (Etrumeus teres) y sardina bocona (Cetengraulis mysticetus). Las primeras cuatro especies aportaron durante la temporada 1995/1996 el 99\% de la captura, siendo la sardina monterrey la principal especie (88\%) (Nevárez-Martínez et al., 1996).

Los pelágicos menores son organismos filtro alimentadores y alimentadores particulados (Radovich, 1952; Hand y Berner, 1959; Ahlstrom, 1960; Ciechomski, 1967; Murphy, 1977; Kawasaki y Kumagai, 1984; Cury y Fontana, 1988; López-Martínez, 1991; Jacob-Cervantes et al., 1992; Molina-Ocampo, 1993). El género Sardinops es miembro de varias comunidades bastante complejas de alimentadores de plancton y puede establecer competencia con otras especies de importancia. Un ejemplo de esto es el 
Ciencias Marinas, Vol. 25, No. 4, 1999

waters off Japan (Kawasaki, 1993) and Australia (Lluch-Belda et al., 1989, 1992). The existence of these competitive communities seems to have an important effect on the fishery of Sardinops on the west coast of North America, in South Africa and Japan (Kawasaki, 1993). Similar effects exist in temperate ecosystems, e.g., the Arctic Ocean, where Clupea is an important representative, or in tropical oceans, where Sardinella dominates (Murphy, 1977).

In the California Current, the diets of some small pelagics have been compared, and although some studies have been conducted in the Gulf of California on the feeding ecology of small pelagic fishes (López-Martínez, 1991; Jacob-Cervantes et al., 1992; Molina-Ocampo, 1993; Robinson and Arenas, 1995; Molina et al., 1996), none has evaluated the overlap in the type and size of the prey that compose the diet and the probable feeding competition among them in this ecosystem. In the present work we analyzed the diet of the Pacific sardine, the thread herring and the northern anchovy, and their possible overlap in the pelagic ecosystem of the Gulf of California.

\section{MATERIAL AND METHODS}

The organisms used for the present analysis were collected during a survey cruise made in August 1993 on board the R/V BIP-XI of the Instituto Nacional de la Pesca (Centro Regional de Investigación Pesquera in Guaymas, Sonora), within the northern and central regions of the Gulf of California (fig. 2). A total of 28 trawls were made from 20:00 to 06:00 hours (since small pelagics form dense schools during the night), with a standard mid-water trawl net at different depths. Specimens of Pacific sardine, northern anchovy and thread herring were collected at all the stations where they were found.

Immediately after the collection, a $10 \%$ formaline solution neutralized with sodium borate was injected into the body cavity to stop the digestive processes of the organisms, which were then frozen. Processing of samples in the complejo interactivo formado por Sardinops, Engraulis, Scomber y Trachurus en la Corriente de California (Murphy, 1977). Comunidades similares se establecen en el sureste de África, y en aguas costeras de Japón (Kawasaki, 1993) y Australia (Lluch-Belda et al., 1989, 1992). La existencia de estas comunidades competitivas parece tener un efecto importante en la pesquería de Sardinops en la costa oeste de América del Norte, en Sudáfrica y Japón (Kawasaki, 1993). Efectos similares existen en los ecosistemas templados, e.g., el Océano Ártico, donde Clupea es un representante importante, o en los océanos tropicales, donde Sardinella domina (Murphy, 1977).

En la Corriente de California se han hecho comparaciones entre las dietas de algunos pelágicos menores, y si bien en el Golfo de California se han hecho algunos estudios sobre la ecología alimenticia de pelágicos menores (López-Martínez, 1991; Jacob-Cervantes, et al., 1992; MolinaOcampo, 1993; Robinson y Arenas, 1995; Molina et al., 1996), ninguno ha evaluado el traslapo en el tipo y tamaño de las presas que componen la dieta y la probable competencia alimenticia entre ellos en este ecosistema. En este trabajo se analiza la dieta de la sardina monterrey, la sardina crinuda y la anchoveta norteña y su posible traslapo en el ecosistema pelágico del Golfo de California.

\section{MATERIAL Y MÉTODOS}

Los organismos usados para el presente análisis fueron obtenidos durante un crucero prospectivo efectuado en agosto de 1993 a bordo del B/O BIP-XI del Instituto Nacional de la Pesca (Centro Regional de Investigación Pesquera en Guaymas, Sonora), en la región centro y norte del Golfo de California (fig. 2). Se efectuaron un total de 28 arrastres a profundidades variables de las 20:00 a las 06:00 horas (debido a que los pelágicos menores forman cardúmenes densos durante la noche), con una red de arrastre de media agua. En las estaciones en que se encontraron ejemplares de sardina monterrey, crinuda y/o anchoveta, éstos fueron recolectados. 
López-Martínez et al.: Overlap in prey in small pelagic fishes of the Gulf of California

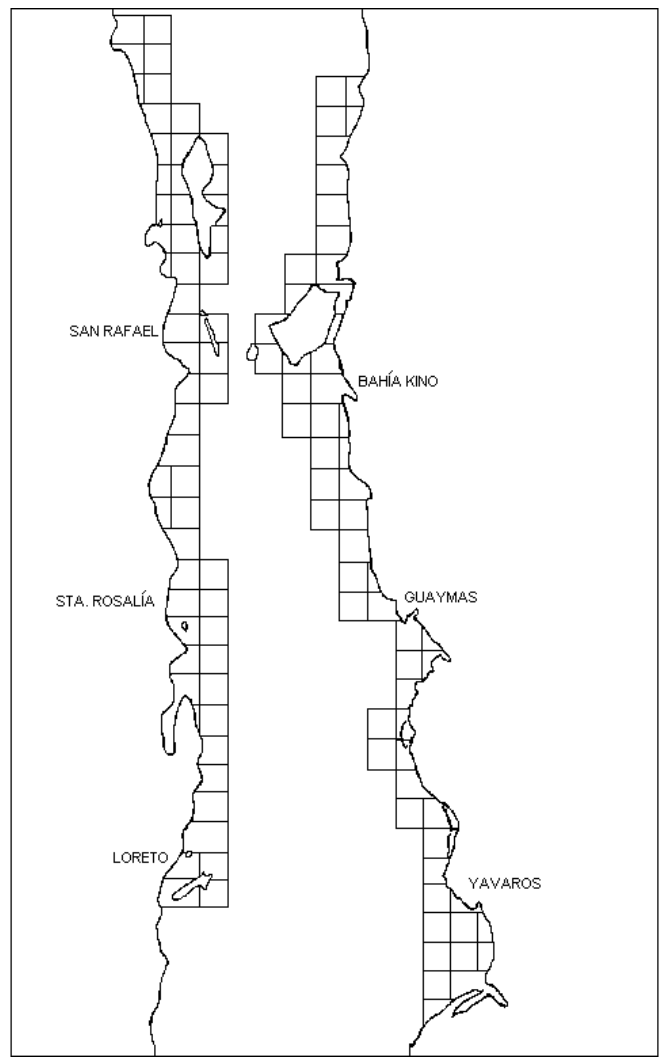

Figure 2. Geographic location of the sampling stations during the August 1993 cruise in the Gulf of California.

Figura 2. Plan de estaciones prospectadas durante el crucero de investigación efectuado en agosto de 1993 en el Golfo de California.

laboratory was as follows: in order to have the feeding groups that compose the diet of the three species as complete as possible, we processed only the stomach contents of the region comprised between the mean part of the esophagus and the pyloric sphincter. The degree of fullness of the organisms was determined following the scale proposed by Aloncle and Delaporte (1970, in Herran, 1988), which goes from 0 (empty stomach) to 4 (full stomach). For the determination of the diet, only the organisms with a degree of fullness of 2 to 4 were considered. The characterization of the diet was accomplished using
Inmediatamente después de la recolección, los organismos fueron inyectados en la cavidad corporal con una solución de formalina al $10 \%$ neutralizada con borato de sodio (para detener los procesos digestivos) y posteriormente fueron congelados. En el laboratorio, con la finalidad de obtener los grupos alimenticios que componen la dieta de las tres especies lo más completos posibles, se procesó únicamente el contenido estomacal de la región comprendida entre el esófago y el esfínter pilórico. El grado de llenado de los organismos fue determinado siguiendo la escala propuesta por Aloncle y Delaporte (1920, en 
Ciencias Marinas, Vol. 25, No. 4, 1999

the numerical percentage index $(\% \mathrm{~N})$ and the percentage of occurrence (\%FO) (Hynes, 1950; Hyslop, 1980). Measurements of the frequency distributions by size of the prey were also obtained. To test the differences between the distributions of particle by species, independence tests through contingency tables were done (Sokal and Rohlf, 1973).

To evaluate the possible food overlap of the three fish species we used the index of specific overlap of Petraitis (1979) using \%N. This index was chosen because it considers the availability of the prey species in the environment (Wallace, 1981). The index measures the overlap in the relative use of the available feeding resource (termed the utilization curve of a resource) between species (Petraitis, 1979). The values of this index go from 0 (no overlap) to 1 (full overlap). The significance of the index of Petraitis was tested with the Wilcoxon $U$ test. All the computations of the index of Petraitis were done using the Statistical Ecology package (Ludwig and Reynolds, 1988).

\section{RESULTS}

Specimens of Pacific sardine, thread herring and northern anchovy were caught in 16 trawls (table 1). Anchovy and thread herring were not found simultaneously at any station, which agrees with the results of previous cruises (SantosMolina, personal comunication, Centro Regional de Investigación Pesquera de Guaymas).

The Pacific sardine was distributed around Ángel de la Guarda and Tiburón islands, while the anchovy was found on the west coast of the Gulf of California and the thread herring scattered throughout the area covered. In general, it was observed that the thread herring was distributed in temperatures of $29^{\circ} \mathrm{C}$ to $31^{\circ} \mathrm{C}$, the anchovy in $27^{\circ} \mathrm{C}$ and the Pacific sardine did not show preference for any temperature in particular and apparently its distribution is related to upwelling areas in the region of the large islands (fig. 3).

A total of 120 Pacific sardines were analyzed of 90 to $180 \mathrm{~mm}$ standard length (SL), 140 thread
Herran, 1988), que va de 0 (estómago vacío) a 4 (estómago lleno). Para la determinación de la dieta, únicamente se consideraron los organismos con llenado de 2 a 4 . La caracterización de la dieta se realizó usando los índices de porcentaje numérico $(\% \mathrm{~N})$ y porcentaje de frecuencia de aparición (\%FO) (Hynes, 1950; Hyslop, 1980). Igualmente, se obtuvo para cada especie de pelágico considerada la distribución de frecuencia de tamaño de la presa. Para probar las diferencias entre las distribuciones de tamaño de partícula entre especies, se efectuaron pruebas de independencia mediante tablas de contingencia (Sokal y Rohlf, 1973).

Para evaluar el posible traslapo alimenticio entre las tres especies de peces, se utilizó el índice de traslapo específico de Petraitis (1979) usando como indicativo de abundancia el porcentaje numérico $(\% \mathrm{~N})$. El índice de Petraitis se eligió debido a que considera la disponibilidad de las especies de presa en el ambiente (Wallace, 1981). El índice mide el traslapo en el uso relativo del recurso alimenticio (llamado la curva de utilización de un recurso) entre especies (Petraitis, 1979). Los valores de este índice van de 0 ( $\sin$ traslapo) a 1 (totalmente traslapados). La significancia del índice se probó mediante una prueba $U$ de Wilcoxon. Todos los cálculos se efectuaron con el paquete estadístico Statistical Ecology (Ludwig y Reynolds, 1988).

\section{RESULTADOS}

En 16 lances fueron obtenidos ejemplares de sardina monterrey, sardina crinuda y/o anchoveta norteña (tabla 1). En ninguna estación se encontró simultáneamente sardina crinuda y anchoveta norteña, lo que concuerda con los resultados de cruceros previos (Santos-Molina, comunicación personal, Centro Regional de Investigación Pesquera de Guaymas).

La sardina monterrey se distribuyó alrededor de las islas Ángel de la Guarda y Tiburón, mientras que la anchoveta se encontró sobre la costa oeste del Golfo de California y la crinuda se encontró dispersa en toda el área cubierta. En general, se observó que la crinuda se distribuyó en 
Table 1. Species present, surface water temperature and catch depth at the stations sampled in the Gulf of California during August 1993.

Tabla 1. Especies de pelágicos menores presentes, temperatura superficial y profundidad de captura en las estaciones de muestreo en el Golfo de California durante agosto de 1993.

\begin{tabular}{cccccc}
\hline Station & $\begin{array}{c}\text { Temperature } \\
\left({ }^{\circ} \mathrm{C}\right)\end{array}$ & $\begin{array}{c}\text { Depth } \\
(\mathrm{m})\end{array}$ & $\begin{array}{c}\text { Sardinops } \\
\text { caeruleus }\end{array}$ & $\begin{array}{c}\text { Engraulis } \\
\text { mordax }\end{array}$ & $\begin{array}{c}\text { Opisthonema } \\
\text { libertate }\end{array}$ \\
\hline 1 & 31.0 & 15 & & & $\mathrm{X}$ \\
2 & 29.0 & 12 & $\mathrm{X}$ & & \\
3 & 29.8 & 15 & $\mathrm{X}$ & & \\
4 & 30.0 & 8 & & & $\mathrm{X}$ \\
5 & 30.0 & 15 & $\mathrm{X}$ & & \\
6 & 29.6 & 12 & & & \\
7 & 28.0 & 20 & $\mathrm{X}$ & & \\
8 & 27.0 & 30 & & $\mathrm{X}$ & \\
9 & 28.5 & 15 & $\mathrm{X}$ & & \\
10 & 28.4 & 12 & $\mathrm{X}$ & & \\
11 & 27.0 & 30 & $\mathrm{X}$ & $\mathrm{X}$ & \\
12 & 26.8 & 30 & & $\mathrm{X}$ & $\mathrm{X}$ \\
13 & 26.8 & 10 & $\mathrm{X}$ & $\mathrm{X}$ & \\
14 & 30.0 & 25 & & & $\mathrm{X}$ \\
15 & 30.8 & 20 & & & \\
16 & 29.5 & 30 & & & \\
\hline
\end{tabular}

herrings of 43 to $230 \mathrm{~mm} \mathrm{SL}$, and 80 anchovies of 80 to $150 \mathrm{~mm}$ SL. All organisms analyzed presented stomach fullness ranging from 2 to 4 (mean full stomach to totally full stomach).

For the anchovy, the diet showed a wide spectrum, with 29 genera of diatoms, 13 of dinoflagellates, some radiolarians, foraminiferans, silicoflagellates and tintinnids. With respect to zooplankton, 12 genera of copepods, brachyuran larvae, euphausiids, mollusk larvae, mysidaceans, polychaetes, amphipods and cladocerans were found. According to the numerical percent $(\% \mathrm{~N})$, the diatoms were the principal food group in temperaturas de $29^{\circ} \mathrm{C}$ a $31^{\circ} \mathrm{C}$, la anchoveta en $27^{\circ} \mathrm{C}$ y la sardina monterrey no mostró preferencia por ninguna temperatura en particular y aparentemente su distribución está más relacionada con las áreas de surgencias en la región de las grandes islas (fig. 3).

Se analizó un total de 120 ejemplares de sardina monterrey de 90 a $180 \mathrm{~mm}$ de longitud estándar (SL), 140 crinudas de 43 a 230 mm SL, y 80 anchovetas de 80 a $150 \mathrm{~mm}$ SL. Todos los organismos presentaron el grado de llenado de los estómagos de 2 a 4 (estómago medio lleno a totalmente lleno). La dieta de la anchoveta presentó un 
Ciencias Marinas, Vol. 25, No. 4, 1999

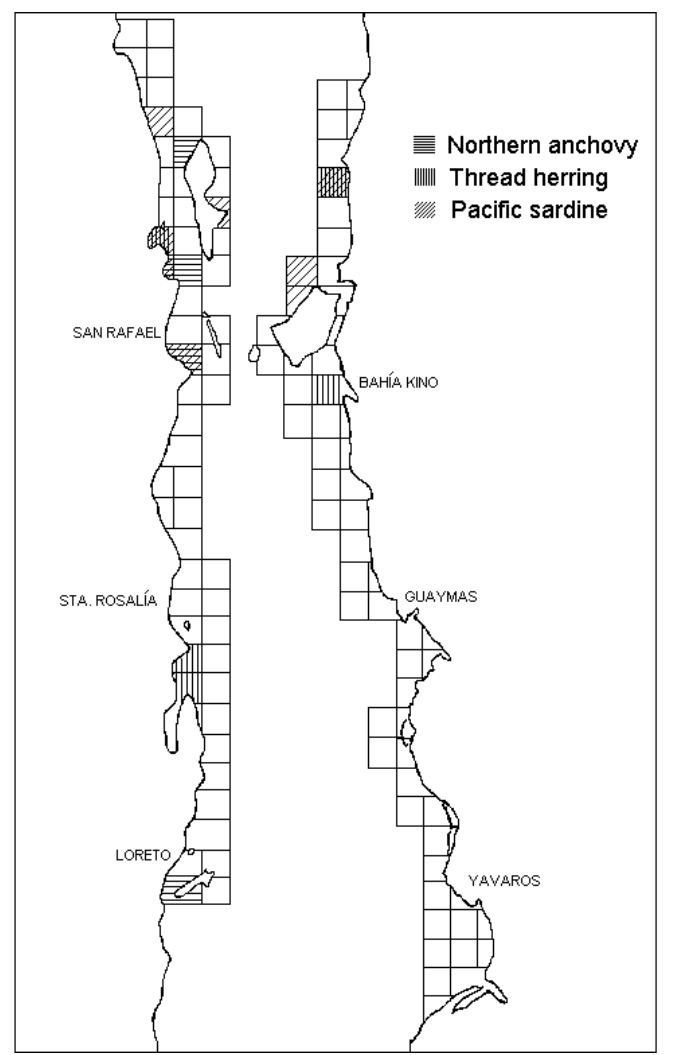

Figure 3. Sea surface temperature and spatial distribution of the Pacific sardine, thread herring and northern anchovy observed in the Gulf of California during August 1993.

Figura 3. Temperatura superficial del mar y distribución espacial de la sardina monterrey, sardina crinuda y anchoveta norteña observada en el Golfo de California durante 1993.

the diet, the most important genera being Thalassionema, Rhizosolenia and Coscinodiscus (fig. 4). The groups of zooplankters represented low values of numerical importance as is the case of some copepods, brachyuran larvae and ichthyoplankton, in addition to other planktonic groups.

For the Pacific sardine, the diet presented a total of 13 genera of phytoplankters, among which prevailed diatoms and dinoflagellates, in addition to 41 genera of zooplankters (the most important being the copepods, followed by brachyuran larvae). Numerically $(\% \mathrm{~N})$, the diatoms were the most important group, in espectro amplio, con 29 géneros de diatomeas, 13 de dinoflagelados, algunos radiolarios, foraminíferos, silicoflagelados y tintínidos. Con respecto al zooplancton, se encontraron 12 géneros de copépodos, larvas de braquiuros, eufáusidos, larvas de moluscos, misidáceos, poliquetos, anfípodos y cladóceros. De acuerdo con el porcentaje numérico $(\% \mathrm{~N})$, el grupo alimenticio principal fueron las diatomeas, siendo los géneros más importantes Thalassionema, Rhizosolenia y Coscinodiscus (fig. 4). Los grupos de zooplancton presentaron valores bajos numéricamente, como es el caso de algunos copépodos, larvas de braquiuros e ictioplancton, además de otros grupos. 


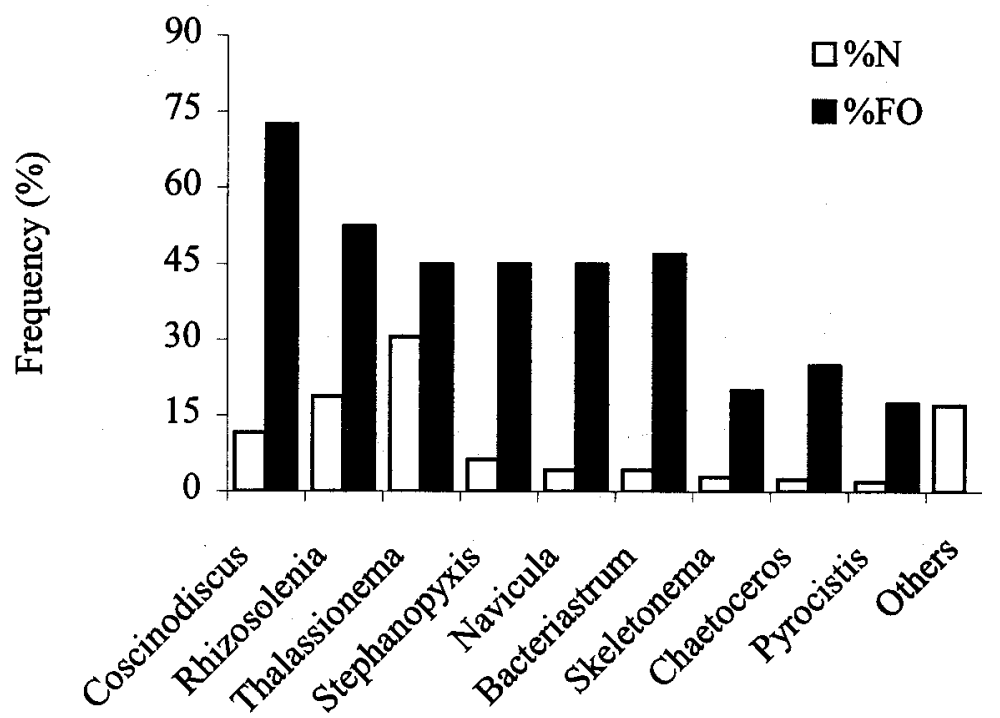

Figure 4. Principal prey in the diet of the northern anchovy Engraulis mordax in the Gulf of California during August 1993.

Figura 4. Presas principales que formaron la dieta de la anchoveta norteña Engraulis mordax en el Golfo de California durante agosto de 1993.

particular the genera Navicula, Dinophysis and Planktoniella. However, the groups that more frequently appeared $(\% \mathrm{FO})$ in the diet were the copepods (mainly Calanus) and brachyuran larvae (fig. 5).

Of the three species of small pelagics studied, the diet of the thread herring had the widest spectrum, with 31 genera of diatoms, 14 of copepods and 13 of dinoflagellates, plus another 28 genera, including euphausiids, ostracods and polychaetes. Our results showed a great dominance of the diatoms, the most frequent genera being Navicula, Rhizosolenia and Bacteriastrum, although Chaetoceros and Pleurosigma were numerically more important (fig. 6). The group of copepods was very frequent but their numerical importance was lower, the most frequent genus being Calanus.

The index of specific overlap (table 2) indicated a slight and significant food overlap between the northern anchovy and the thread herring ( $\mathrm{SO}=0.76 ; P=0.05$ ). The food overlap
En la dieta de la sardina monterrey se presentaron un total de 13 géneros de fitoplancton, entre los que predominaron las diatomeas y dinoflagelados, además de 41 géneros de zooplancton (siendo más importantes los copépodos y las larvas de braquiuros). Numéricamente $(\% \mathrm{~N})$, el grupo de las diatomeas fue el más importante, en particular los géneros Navicula, Dinophysis y Planktoniella. Sin embargo, los grupos que más frecuentemente aparecieron $(\% \mathrm{FO})$ en la dieta fueron los copépodos (principalmente Calanus) y las larvas de braquiuros (fig. 5).

De las tres especies de pelágicos menores investigadas, la dieta de la sardina crinuda presentó el espectro más amplio, con 31 géneros de diatomeas, 14 de copépodos y 13 de dinoflagelados, además de otros 28 géneros, incluyendo eufáusidos, ostrácodos y poliquetos. Los resultados mostraron un fuerte predominio numérico de las diatomeas, siendo los géneros más frecuentes Rhizosolenia, Navicula y Bacteriastrum, si bien Chaetoceros y Pleurosigma fueron 


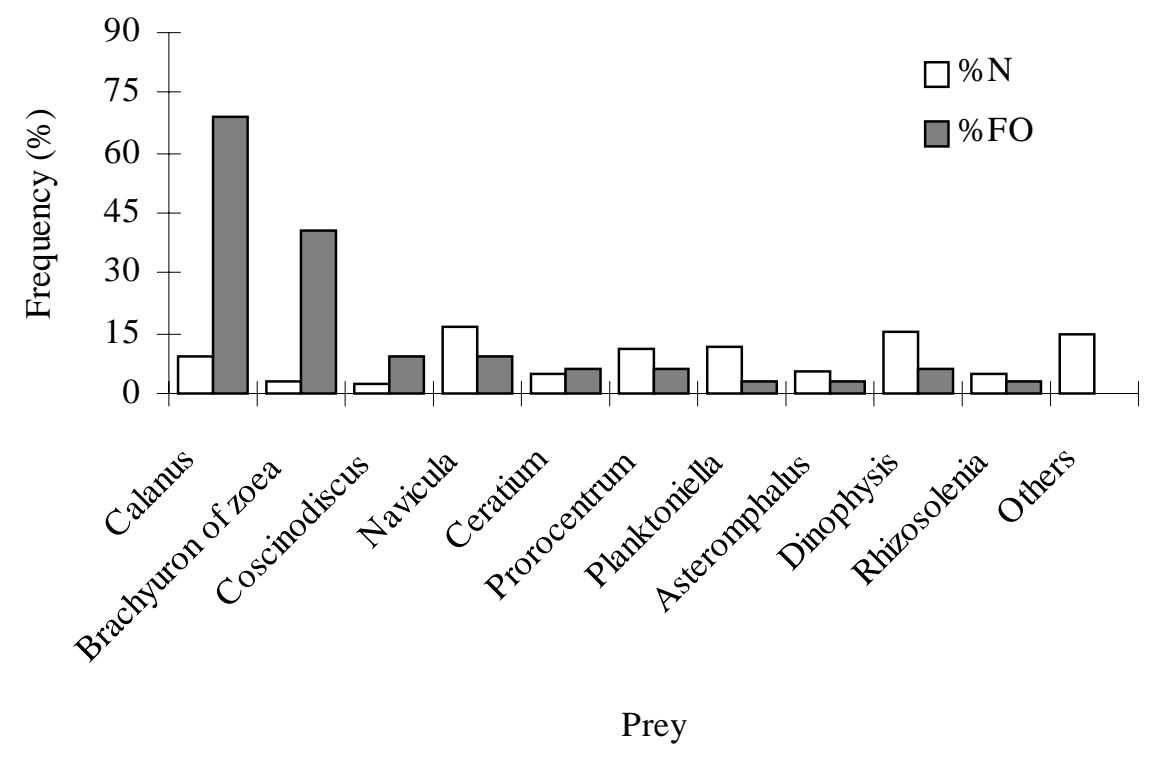

Figure 5. Principal prey in the diet of the Pacific sardine Sardinops caeruleus in the Gulf of California during August 1993.

Figura 5. Presas principales que formaron la dieta de la sardina monterrey Sardinops caeruleus en el Golfo de California durante agosto de 1993.

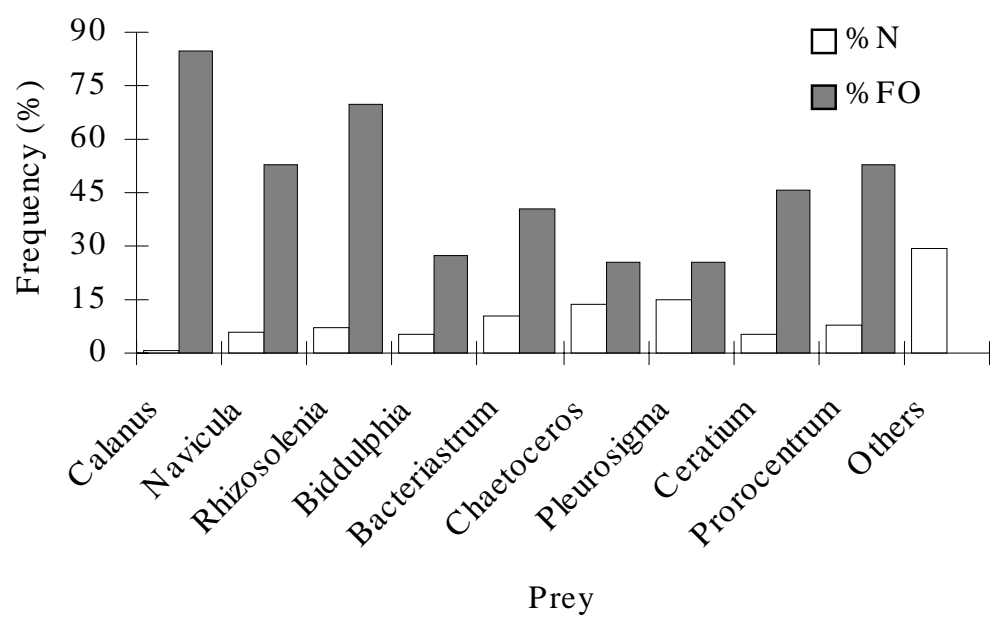

Figure 6. Principal prey in the diet of the thread herring Opisthonema libertate in the Gulf of California during August 1993.

Figura 6. Presas principales que formaron la dieta de la sardina crinuda Opisthonema libertate en el Golfo de California durante agosto de 1993. 
Table 2. Values of the specific diet-overlap index (SO) for the northern anchovy Engraulis mordax, thread herring Opisthonema libertate and Pacific sardine Sardinops caeruleus in the Gulf of California; Wilcoxon $U$ test and degrees of freedom (d.f.) $(P=0.05)$.

Tabla 2. Valores del índice de traslapo específico de dieta (SO) para la anchoveta norteña Engraulis mordax, sardina crinuda Opisthonema libertate y sardina monterrey Sardinops caeruleus en el Golfo de California; prueba de significancia de Wilcoxon $(U)$ y grados de libertad (d.f.) $(P=0.05)$.

\begin{tabular}{lccc}
\hline Species & SO & $U$ & d.f. \\
\hline Anchovy - thread herring & 0.76 & 5.095 & 112 \\
Thread herring - anchovy & 0.40 & 10.682 & 112 \\
Anchovy - Pacific sardine & 0.00 & 16.310 & 112 \\
Pacific sardine - anchovy & 0.49 & 7.262 & 112 \\
Thread herring - Pacific sardine & 0.05 & 17.359 & 112 \\
Pacific sardine - thread herring & 0.02 & 9.001 & 112 \\
\hline
\end{tabular}

was not significant between the Pacific sardine and the northern anchovy, or between the Pacific sardine and the thread herring. The significant overlap was between the trophic spectrum of the northern anchovy on the utilization curve of the thread herring; however, the overlap was not significant between the trophic spectrum of the thread herring on the utilization curve of the anchovy. This can be explained if it is considered that the thread herring has a nutritional niche breadth.

With respect to the particle size preferably ingested by the three species, the Pacific sardine had the widest range of particle size, with approximately $80 \%$ of the diet concentrated in particles of 350 to $750 \mu \mathrm{m}$, with the peak at $550 \mu \mathrm{m}$. The northern anchovy ingested organisms ranging between 150 and $650 \mu \mathrm{m}$, with the peak at about $650 \mu \mathrm{m}$, while the thread herring ingested prey between 150 and $350 \mu \mathrm{m}$, with a peak at $150 \mu \mathrm{m}$ (fig. 7). The size of ingested particles differs largely among the three species $\left(\chi^{2}=178 ; P=0.001\right)$.

\section{DISCUSSION}

The results presented here indicate that the three fish species analyzed are thought of as numéricamente más importantes (fig. 6). El grupo de copépodos fue el más frecuente, pero su importancia numérica muy baja, siendo el género más frecuente Calanus.

El índice de traslapo específico (tabla 2) indicó un traslapo significativo entre la anchoveta norteña y la sardina crinuda $(\mathrm{SO}=0.76 ; P=$ 0.05). El traslapo alimenticio no fue significativo entre la sardina monterrey y la anchoveta norteña, ni entre la sardina monterrey y la crinuda. El traslapo significativo fue entre la curva de utilización de la anchoveta norteña sobre la curva de utilización de la sardina crinuda; sin embargo, el traslapo no fue importante entre la curva de utilización de la crinuda sobre la curva de utilización de la anchoveta. Esto puede explicarse si se considera que la crinuda tiene una mayor amplitud de nicho.

Con respecto al tamaño de partícula ingerido preferentemente por las tres especies, la sardina monterrey tuvo el mayor rango de tamaños de partículas, con aproximadamente $80 \%$ de la dieta compuesta de partículas de 350 a $750 \mu \mathrm{m}$, con un pico en $550 \mu \mathrm{m}$. La anchoveta norteña ingirió organismos con tamaños entre 150 y $650 \mu \mathrm{m}$, con un pico en $650 \mu \mathrm{m}$, mientras que la sardina crinuda ingirió presas entre 150 y $350 \mu \mathrm{m}$, con un pico en $150 \mu \mathrm{m}$ (fig. 7). El tamaño de partículas 


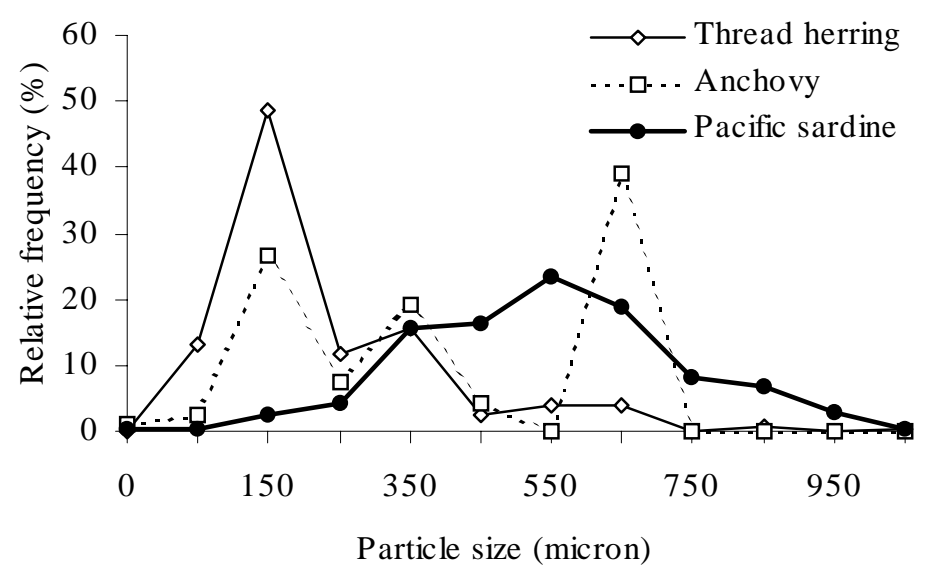

Figure 7. Relative frequency of prey size in the diet of the Pacific sardine, thread herring and northern anchovy in the Gulf of California.

Figura 7. Distribución de la frecuencia relativa del tamaño de partícula presente en la dieta de la sardina monterrey, sardina crinuda y anchoveta norteña en el Golfo de California.

plankton-feeders that occupy the second and third trophic levels. They play the role of both a herbivorous or primary consumer feeding on phytoplankton and a carnivorous feeder or secondary consumer feeding on zooplankters. It is difficult to determine the exact degree of preference and apparently this is a function of their availability in the plankton. Consequently, the diet can be highly dependent upon the dispersion patterns of the plankton. According to our results, it can be considered that the three species are opportunist grazers (López-Martínez, 1991; Jacob-Cervantes et al., 1992; Molina and Manrique, 1994; LópezMartínez et al., 1994; Robinson and Arenas, 1995). In ecological terms, this fact is of great advantage for these species, because organisms with generalist nutritional habits can cover their metabolic requirements with a great variety of prey species, in this case only limited by their holding capacity due to the fact that they are filter-feeding organisms (King and MacCleod, 1976; López-Martínez, 1991).

Significant overlap was found between the diet of the northern anchovy and the diet of the ingeridas difiere significativamente entre las tres especies $\left(\chi^{2}=178 ; P=0.001\right)$.

\section{DISCUSIÓN}

Los resultados presentes indican que las tres especies de peces analizadas pueden considerarse como alimentadores de plancton, ocupando el segundo y tercer nivel trófico. Dentro del ecosistema juegan el papel tanto de un consumidor herbívoro o primario cuando se alimentan de fitoplancton y de un alimentador carnívoro o consumidor secundario cuando se alimentan de zooplancton (Blaxter y Hunter, 1982). Es difícil determinar el grado exacto de preferencia y aparentemente está en función de su disponibilidad en el plancton. Consecuentemente, la dieta puede ser altamente dependiente de los patrones de dispersión del plancton. Según los resultados, puede considerarse que las tres especies son alimentadores oportunistas (López-Martínez, 1991; JacobCervantes et al., 1992; Molina y Manrique, 1994; López-Martínez et al., 1994; Robinson y Arenas, 1995). En términos ecológicos, este hecho es una 
thread herring. However, considering the distribution pattern presented in this work and taking into account that the anchovy and the thread herring appear together very rarely in field samples (Santos-Molina, personal comunication, Centro Regional de Investigación Pesquera de Guaymas), the probability of competition between them is minimal.

Due to the very high primary productivity of the Gulf of California (Álvarez-Borrego, 1983; Brinton et al., 1986; Valdez-Holguín and LaraLara, 1987), which can sustain planktonic organisms with biomass as high as $16,000,000 \mathrm{org} / \mathrm{m}^{3}$ (López-Martínez et al., 1994), the competition for food among the Pacific sardine, the northern anchovy and the thread herring is considered unlikely. These results do not support the hypothesis of a possible competition for food between the Pacific sardine and the northern anchovy in the pelagic ecosystem of the Gulf of California (Molina-Ocampo, 1993; LópezMartínez et al., 1994; Cisneros-Mata et al., 1995). In the present work, the Pacific sardine and the northern anchovy were found simultaneously at 4 of the 16 stations, yet a significant overlap was not found in their diet; besides, the particle length was different between these species. The prey size ingested was more related to the gillraker gap existing in the filtering apparatus of these species, of $160 \mu \mathrm{m}$ in the Pacific sardine (López-Martínez, 1991), $115 \mu \mathrm{m}$ in the northern anchovy (Jacob-Cervantes et al., 1992; MartínezTortolero and Manrique-Colchado, 1994) and 80 $\mu \mathrm{m}$ in the thread herring (López-Martínez and Manrique-Colchado, 1994; López-Martínez et al., 1994).

The fact that the thread herring has a broader food spectrum than the other two species is explained mainly by the greater capacity of withholding small particles by having a fine filtering apparatus, which gives it an advantage with respect to both the Pacific sardine and the northern anchovy, e.g., in situations such as those during an El Niño when there is an increase in micro- and nanoplankton (Valdez-Holguín and gran ventaja para estas especies, porque los organismos con hábitos alimenticios generalistas pueden cubrir sus requerimientos metabólicos con una gran variedad de especies de presa, en este caso limitados únicamente por su capacidad de retención, debido a que son organismos filtroalimentandores (King y MacCleod, 1976; LópezMartínez, 1991). El único traslapo significativo fue entre la dieta de la anchoveta norteña y la dieta de la sardina crinuda. Sin embargo, considerando la distribución observada de estas especies durante el crucero y tomando en cuenta que la anchoveta y la crinuda aparecen muy raras veces juntas en muestreos de campo (Santos-Molina, comunicación personal, Centro Regional de Investigación Pesquera de Guaymas), la probabilidad de competencia entre ellas es mínima.

Considerando la alta productividad primaria del Golfo de California (Álvarez-Borrego 1983; Brinton et al., 1986; Valdez-Holguín y Lara-Lara, 1987), es poco probable la competencia por alimento entre la sardina monterrey, la anchoveta norteña y la sardina crinuda. Los resultados aquí presentados no apoyan la hipótesis que ha sido planteada (Molina-Ocampo, 1993; LópezMartínez et al., 1994; Cisneros-Mata et al., 1995), de una posible competencia por alimento entre la sardina monterrey y la anchoveta norteña en el ecosistema pelágico del Golfo de California. Si bien la sardina monterrey y la anchoveta norteña se encontraron simultáneamente en 4 de las 16 estaciones positivas, no hubo un traslapo significativo en su dieta, ni en tipo ni en tamaño de presa ingerido. El tamaño de presa ingerido estuvo más relacionado con el espacio interbranquiespinal existente en el aparato de filtración de estas especies, que es de $160 \mu \mathrm{m}$ en la sardina monterrey (López-Martínez, 1991), $115 \mu \mathrm{m}$ en la anchoveta norteña (Jacob-Cervantes et al., 1992; MartínezTortolero y Manrique-Colchado, 1994) y $80 \mu \mathrm{m}$ en la crinuda (López-Martínez y ManriqueColchado, 1994; López-Martínez et al., 1994).

El hecho de que la crinuda tenga un espectro alimenticio más amplio que el de las otras dos especies se explica principalmente por la mayor 
Ciencias Marinas, Vol. 25, No. 4, 1999

Lara-Lara, 1987). This fact, combined with more tolerance to warm water (Molina-Valdez et al. 1984), can explain the high availability and high catch of thread herring in the Gulf of California during El Niño events (Molina-Valdez et al., 1984; Lluch-Belda et al., 1986; Cisneros-Mata et al., 1987; Hammann et al., 1988; NevárezMartínez, 1990).

These results are important in the context of the management of the fisheries, since it has been mentioned that in the small pelagic fishery of the Gulf of California, the northern anchovy is the species that has a greater probability of replacing the Pacific sardine, which due to the high levels of fishing that this species has undergone and interspecific relationships, has shown evidence of decreasing in abundance (Cisneros-Mata et al., 1995). However, in the total catch, this was not observed in the $1990 / 1993$ period of lower catch, since it was the thread herring that sustained the fishery during these years (Cisneros-Mata et al., 1991; NevárezMartínez et al., 1993; Cisneros-Mata et al., 1995). Furthermore, in terms of nutrition and tolerance to temperatures, it seems more probable that the thread herring is the species that could take over the Pacific sardine, as has been observed in El Niño years, which have a negative effect on the Pacific sardine and northern anchovy. Therefore, it would be advisable to have a better follow-up of these species.

\section{ACKNOWLEDGEMENTS}

Funds for this study were provided by the Fondo del Sistema de Investigación del Mar de Cortés, A.C. (SIMAC94/CM-009) to the Instituto Tecnológico y de Estudios Superiores de Monterrey, Campus Guaymas, where this study was conducted. We thank the personnel of the Programa para el Estudio de los Pelágicos Menores (CRIP-Guaymas), and in particular $\mathrm{J}$. Pablo Santos-Molina and Miguel A. CisnerosMata for reading the manuscript and providing constructive comments. capacidad de retención de partículas pequeñas de su aparato de filtración, lo que le confiere ventaja con respecto a la sardina monterrey y la anchoveta norteña, e.g., en situaciones tales como durante un evento El Niño cuando hay un aumento en el micro y nanoplancton (Valdez-Holguín y LaraLara, 1987). Este hecho, combinado con una mayor tolerancia a aguas cálidas (Molina-Valdez et al., 1984), puede explicar, en el Golfo de California, la disponibilidad y altas capturas de sardina crinuda con respecto a las de sardina monterrey durante eventos El Niño (Molina-Valdez et al., 1984; Lluch-Belda et al., 1986; CisnerosMata et al., 1987; Hammann et al., 1988; Nevárez-Martínez, 1990).

Estos resultados son importantes en el marco de la administración de pesquerías, debido a que se ha mencionado que en la pesquería de pelágicos menores del Golfo de California, la anchoveta norteña es la especie con mayor probabilidad de reemplazar a la sardina monterrey que, debido a los altos niveles de pesca a los que ha sido sometida y a relaciones interespecíficas, ha mostrado evidencias de estar disminuyendo en abundancia (Cisneros-Mata et al., 1995). Sin embargo, en las capturas esto no se vio reflejado durante el periodo de bajas capturas de esta pesquería (1990 a 1993), pues fue la sardina crinuda la que, en esos años, sostuvo a la pesquería (Cisneros-Mata et al., 1991; Nevárez-Martínez et al., 1993; Cisneros-Mata et al., 1995). Además, en términos alimenticios y de tolerancia a la temperatura, parece más probable que sea la sardina crinuda quien pudiera sustituir a la sardina monterrey, como ha sido observado durante los años en que se han presentado eventos El Niño, los cuales tienen un efecto negativo en la población de sardina monterrey y de anchoveta. Por lo anterior, sería recomendable tener un mayor seguimiento de las dos especies de sardina.

\section{AGRADECIMIENTOS}

Los fondos para este estudio fueron proporcionados por el Fondo del Sistema de Investigación del Mar de Cortés, A.C. (SIMAC94/ 


\section{REFERENCES}

Ahlstrom, E.H. (1960). Synopsis on the biology of the Pacific sardine (Sardinops caerulea). Fish. Biol., 17: 415-451.

Álvarez-Borrego, S. (1983). Gulf of California. In: B.H. Ketchum (ed.), Estuaries and Enclosed Seas. Elsevier Scientific, Amsterdam, pp. 427-449.

Blaxter, J.H.S. and Hunter, J.R. (1982). The biology of the clupeoid fishes. Adv. Mar. Biol., 20: 1-223.

Brinton, E., Fleminger, A. and Siegel, D.C. (1986). The temperate and tropical planktonic biotas of the Gulf of California. CalCOFI Rep., 27: 228-266.

Ciechomski, Dz. J. (1967). Investigations of food and feeding habits of larvae and juveniles of the Argentine anchovy Engraulis anchoita. CalCOFI Rep., 11: 72-81.

Cisneros-Mata, M.A., Santos-Molina, J.P., de Anda M., J.A., Sánchez, A. y Estrada G., J.J. (1987). Pesquería de sardina en el noroeste de México. SEPESCA, Instituto Nacional de la Pesca (CRIP, Calle 20 No. 605 Sur, Guaymas, Sonora, México), $78 \mathrm{pp}$.

Cisneros-Mata, M.A., Nevárez-Martínez, M.O., Montemayor-López, G., Santos-Molina, J.P. y Morales-Azpeitia, R. (1991). Pesquería de sardina en el Golfo de California 1988/89-1989/90. SEPESCA, Instituto Nacional de la Pesca (CRIP, Guaymas, Sonora, México), 80 pp.

Cisneros-Mata, M.A., Nevárez-Martínez, M.O. and Hammann, M.G. (1995). The rise and fall of the Pacific sardine, Sardinops sagax caeruleus Girard, in the Gulf of California, Mexico. CalCOFI Rep., 36: 136-143.

Csirke, J. (1995). Fluctuations in abundance of small and mid-size pelagics. Sci. Mar., 59(3-4): 481-490.

Cury, P. and Fontana, A. (1988). Compétition et stratégies démographiques comparées de deux espèces de sardinelles (Sardinella aurita et Sardinella maderensis) des côtes ouest-africaines. Aquat. Living Resour., 1: 165-180.

Hammann, M.G., Baumgartner, T. and Badan-Dangon, A. (1988). Coupling of the Pacific sardine (Sardinops sagax caeruleus) life cycle with the Gulf of California pelagic environment. CalCOFI Rep., 29: 102-109.

Hand, C.H. and Berner, L. Jr. (1959). Food of the Pacific sardine Sardinops caerulea. US Fish Wildl. Serv., Fish. Bull., 60(164): 175-184.
CM-009) al Instituto Tecnológico y de Estudios Superiores de Monterrey, Campus Guaymas, en donde se realizó la mayor parte de esta investigación. Se agradece al personal del Programa para el Estudio de los Pelágicos Menores del CRIP-Guaymas y en particular a J. Pablo SantosMolina y Miguel A. Cisneros-Mata por la revisión del manuscrito y sus acertados comentarios.

Traducido al español por los autores.

Herran, R.A. (1988). The analysis of stomach contents in fishes. A review of the literature, the main objectives and methodology. Inf. Tec. Inst. Esp. Oceanogr., (63): 74 pp.

Hynes, H.B.N. (1950). The food of freshwater sticklebacks (Gasterosteus aculeatus and Pygosteus pungitius), with a review of methods used in studies of the food of fishes. J. Animal Ecol., 19: 35-38.

Hyslop, E.J. (1980). Stomach contents analysis. A review of methods and their application. J. Fish. Biol., 17(4): 411-429.

Jacob-Cervantes, M., Gallardo-Cabello, M., ChiappaCarrara, X. y Ruiz-Luna, A. (1992). Régimen alimentario de la sardina crinuda Opisthonema libertate (Pisces: Clupeidae) en el Golfo de California. Rev. Biol. Trop., 40(2): 233-238.

Kawasaki, T. (1993). Recovery and collapse of the Far Eastern sardine. Fish. Oceanogr., 2(3-4): 244-253.

Kawasaki, T. and Kumagai, A. (1984). Food habits of the Far Eastern sardine and their implication in the fluctuation pattern of sardine stocks. Bull. Jap. Soc. Sci. Fish., 50: 1657-1663.

King, D.P.F. and MacCleod, R. (1976). Comparison of the food and the filtering mechanism of pilchard Sardinops ocellata and anchovy Engraulis capensis off Southwest Africa, 1971-1972. Inv. Rep. Sea Fish. Branch S. Afr., 111: 1-29.

Lluch-Belda, D., Magallón, F.J. and Schwartzlose, R.A. (1986). Large fluctuations in the sardine fishery in the Gulf of California: Possible causes. CalCOFI Rep., 27: 136-140.

Lluch-Belda, D., Crawford, R.J.M., Kawasaki, T., MacAll, A.D., Parrish, R.H., Schwartzlose, R.A. and Smith, P.E. (1989). World-wide fluctuations of sardine and anchovy stocks: the regimen problem. S. Afr. J. Mar. Sci., 8: 195-205. 
Ciencias Marinas, Vol. 25, No. 4, 1999

Lluch-Belda, D., Schwartzlose, R.A., Serra, R., Parrish, R., Kawasaki, T., Hedgecock, D. and Crawford, J.M. (1992). Sardine and anchovy regime fluctuations of abundance in four regions af the world oceans: a workshop report. Fish. Oceanogr., 1(4): 339-347.

Lluch-Belda, D. et al. (1994). Estado actual de la pesquería de sardina y anchoveta. Tomo III. Peces. En: Pesquerías Relevantes de México. SEPESCA, Instituto Nacional de la Pesca, México, DF. Ver. CD.

López-Martínez, J. (1991). Alimentación de juveniles y adultos de sardina monterrey Sardinops sagax caeruleus (Girard), en el norte de Isla Tiburón durante el invierno de 1990. Tesis de maestría, CICESE, Ensenada, BC, México, 127 pp.

López-Martínez, J. y Manrique-Colchado. F.A. (1994). Alimentación de la sardina crinuda Opisthonema libertate en la parte norte y centro del Golfo de California durante el verano de 1993. Resúmenes, X Simpósium Internacional de Biología Marina, Ensenada, BC, México, p. 102.

López-Martínez, J., Martínez-Tortolero, H. y Manrique-Colchado, F.A. (1994). Alimentación de anchoveta norteña Engraulis mordax en la parte norte y centro del Golfo de California durante el verano de 1993. Abstract, Annual Conference, CalCOFI, Lake Tahoe, California, p.15.

Ludwig, J.A. and Reynolds, J.F. (1988). Statistical Ecology. A Primer on Methods and Computing. Wiley-Interscience, $337 \mathrm{pp}$.

Martínez-Tortolero, H. y Manrique-Colchado, F.A. (1994). Caracterización del aparato filtrador de la anchoveta norteña Engraulis mordax en el Golfo de California. Resúmenes, V Congreso de la Asociación de Investigadores del Mar de Cortés, La Paz, BCS, México.

Molina-Ocampo, R.E. (1993). Hábitos alimenticios de peces pelágicos menores de importancia comercial del Golfo de California, México. Tesis de maestría, Instituto Tecnológico y de Estudios Superiores de Monterrey, Campus Guaymas, México, $107 \mathrm{pp}$.

Molina, R.E. y Manrique, F.A. (1994). Aplicación de dos nuevos índices numéricos a la ecología alimenticia de tres Clupeiformes del Golfo de California. Univ. Cien.,11: 37-42.

Molina, R.E., Manrique, F.A. and Velazco, H.E. (1996). Filtering apparatus and feeding of the
Pacific mackerel, Scomber japonicus, in the Gulf of California. CalCOFI Rep., 37: 251-256.

Molina-Valdez, D., Páez-Barrera, F., Magallón-Barajas, F.J., Castro-F., F.A. y Castro-Aguirre, C. (1984). Análisis biológico pesquero de la pesquería de sardina en el puerto de Guaymas, Sonora. SEPESCA, Instituto Nacional de la Pesca (CRIP, Guaymas, Sonora, México), 276 pp.

Murphy, G.I. (1977). Clupeoids. In: J.A. Gulland (ed.), Fish Population Dynamics. Wiley-Interscience, New York, pp. 283-308.

Nevárez-Martínez, M.O. (1990). Producción de huevos de la sardina monterrey (Sardinops sagax caeruleus) en el Golfo de California: una evaluación y crítica. Tesis de maestría, CICESE, Ensenada, BC, México, 144 pp.

Nevárez-Martínez, M.O. and Santos-Molina, J.P. (1996). Small pelagic fisheries of the Gulf of California. 1995/96 fishing season. Abstracts, Annual Conference CalCOFI, Asilomar Conference Center, California, p. 10.

Nevárez-Martínez, M.O., Morales-Azpeitia, R., Martínez-Zavala, M.A., Santos-Molina, J.P. y Cisneros-Mata, M.A. (1993). Pesquería de pelágicos menores en el Golfo de California. Temporada 1990/91. SEPESCA, Instituto Nacional de la Pesca (CRIP, Guaymas, Sonora, México), 70 pp.

Nevárez-Martínez, M.O., Cisneros-Mata, M.A., Martínez-Zavala, M.A. and Santos-Molina, J.P. (1998). Performance of two methods to estimate yield for the Pacific sardine of the Gulf of California, Mexico. Oceanides, 13(1): 31-39.

Petraitis, S.P. (1979). Likelihood measures of niche breadth and overlap. Ecology, 60(4): 703-710.

Radovich, J. (1952). Food of the Pacific sardine, Sardinops caerulea from central Baja California and southern California. Calif. Fish Game, 38(4): $575-585$.

Robinson, C. and Arenas, V. (1995). Evidence of different feeding rates within an anchovy shoal. Ciencias Marinas, 21(3): 281-293.

Sokal, R.R. and Rohlf, F.J. (1973). Biometry. W.H. Freeman, New York, 859 pp.

Valdez-Holguín, E. y Lara-Lara, R. (1987). Productividad primaria en el Golfo de California. Efectos del evento El Niño 1982-1983. Ciencias Marinas, 13(2): 34-50.

Wallace, R.K. Jr. (1981). An assessment of diet-overlap index. Trans. Am. Fish. Soc., 110: 72-76. 